\title{
Inherited Variation in Cytokine, Acute Phase Response, and Calcium Metabolism Genes Affects Susceptibility to Infective Endocarditis
}

\author{
Anastasia V. Ponasenko, ${ }_{1}^{1}$ Anton G. Kutikhin, ${ }^{1}$ Maria V. Khutornaya, ${ }^{1}$ \\ Natalia V. Rutkovskaya, ${ }^{1}$ Natalia V. Kondyukova, ${ }^{1}$ Yuri N. Odarenko, ${ }^{1}$ Yana V. Kazachek, \\ Anna V. Tsepokina, ${ }^{1}$ Leonid S. Barbarash, ${ }^{1}$ and Arseniy E. Yuzhalin ${ }^{2}$ \\ ${ }^{1}$ Research Institute for Complex Issues of Cardiovascular Diseases, Sosnovy Boulevard 6, Kemerovo 650002, Russia \\ ${ }^{2}$ Department of Oncology, CRUK/MRC Oxford Institute for Radiation Oncology, University of Oxford, Old Road Campus Research \\ Building, Roosevelt Drive, Oxford OX3 7DQ, UK \\ Correspondence should be addressed to Anton G. Kutikhin; antonkutikhin@gmail.com
}

Received 5 December 2016; Revised 26 March 2017; Accepted 19 April 2017; Published 4 June 2017

Academic Editor: Anshu Agrawal

Copyright (c) 2017 Anastasia V. Ponasenko et al. This is an open access article distributed under the Creative Commons Attribution License, which permits unrestricted use, distribution, and reproduction in any medium, provided the original work is properly cited.

\begin{abstract}
Infective endocarditis (IE) is a septic inflammation of the endocardium. Recognition of microbial patterns, cytokine and acute phase responses, hemostasis features, and alterations in plasma lipid and calcium profile all have been reported to affect pathogenesis and clinical course of IE. Having recruited 123 patients with IE and 300 age-, sex-, and ethnicity-matched healthy blood donors, we profiled their genomic DNA for 35 functionally significant polymorphisms within the 22 selected genes involved in the abovementioned pathways, with the further genetic association analysis. We found that the G/A genotype of the rs1143634 polymorphism within the IL1B gene, the G/T genotype of the rs3212227 polymorphism within the IL12B gene, the A/G genotype of the rs1130864 polymorphism within the CRP gene, and the G allele of the rs 1801197 polymorphism within the CALCR gene were associated with a decreased risk of IE whereas the T/T genotype of the rs1205 polymorphism within the CRP gene was associated with a higher risk of IE. Furthermore, heterozygous genotypes of the rs1143634 and rs3212227 polymorphisms were associated with the higher plasma levels of IL-1 $\beta$ and IL-12, respectively. Our results indicate that inherited variation in the cytokine, acute phase response, and calcium metabolism pathways may be linked to IE.
\end{abstract}

\section{Introduction}

Infective endocarditis (IE) is defined as an infection of the endocardial surface, which may involve native or prosthetic heart valves, the mural endocardium, interventricular septum, chordae tendineae, or surfaces of intracardiac devices [1]. In general, IE is caused by bacteria, in particular Staphylococcus, Streptococcus, and Enterococcus spp. [2], but fungi have also been reported as a culprit [3]. The most common signs and symptoms of IE are malaise, fatigue, coughing, chills, fever, weight loss, and heart murmur [1]. Incidence of IE significantly varies in different countries (from 1.5/
100,000 in Netherlands to $11.6 / 100,000$ in United States), with an average case fatality rate of $25 \%$ [4]. However, case fatality rates considerably depend on the etiological agent: from $10 \%$ in patients infected with Streptococcus spp. to $40 \%$ in those infected with Staphylococcus aureus [5-9]. The development and course of IE may depend on (1) the recognition of pathogen-associated molecular patterns as well as cytokine and acute phase response to causative agents [10-12], (2) hemostasis [13-15], (3) plasma lipid profile $[16,17]$, and (4) plasma calcium profile $[18,19]$.

Progress in genotyping technologies reasoned the studies on the association of single nucleotide polymorphisms 
TABLE 1: Characteristics of the study population.

\begin{tabular}{lccc}
\hline & Controls & Cases & Total \\
\hline Number of subjects & $300(70.92 \%)$ & $123(29.07 \%)$ & $423(100.00 \%)$ \\
Median age with 95\% CI & $55.00(53.00-56.00)$ & $50.00(48.00-53.00)$ & $53.00(52.00-55.00)$ \\
Interquartile range & $44-62$ & $37-59$ & $42-61$ \\
Males & $190(63.00 \%)$ & $77(63.00 \%)$ & $267(63.12 \%)$ \\
Females & $110(37.00 \%)$ & $46(37.00 \%)$ & $156(36.88 \%)$ \\
\hline
\end{tabular}

CI: confidence interval.

(SNPs) with human diseases [20]. SNPs located in different genomic regions may cause distinct consequences, including altered (1) transcription initiation; (2) mRNA splicing; (3) protein folding, stability, and expression; and (4) posttranslational modifications [21]. Previously, we reported that the $\mathrm{C} / \mathrm{C}$ genotype of the rs3775073 polymorphism within the TLR6 gene is associated with a twofold decreased risk of IE; other polymorphisms within the genes encoding pattern recognition receptors did not show a predictive value. Here, we investigated whether the SNPs within the cytokine, acute phase response, lipid metabolism, and calcium metabolism genes can alter individual susceptibility to IE.

\section{Materials and Methods}

2.1. Population. Inclusion criteria were as follows: (1) living in Kemerovo region for $\geq 2$ generations; (2) Russian ethnicity; (3) clinically (modified Duke criteria, at least 1 major and 1 minor criteria or 3 minor criteria being fulfilled [22]) and histologically verified diagnosis of IE; and (4) written informed consent. Exclusion criteria were as follows: (1) belonging to the immigrant or aboriginal populations, (2) previous cancer diagnosis, (3) concomitant mental disorders and/or autoimmune diseases, (4) drug addiction, and (5) refusal to sign a written informed consent. All the patients underwent antibiotic therapy in the acute phase during the first admission to their district hospital according to the European guidelines [22]. Antibiotic therapy and treatment of all concomitant diseases were further performed during the preoperative period at the Kemerovo Cardiology Centre.

In total, we recruited 161 patients with IE admitted to our Research Institute during 2009-2016. After exclusion of 38 patients due to the abovementioned criteria, the study group finally included 123 patients (Table 1). The control group for this study was formed from 300 age- ( \pm 6 years), sex-, and ethnicity-matched asymptomatic blood donors with no history of drug addiction, cardiovascular disease, cancer, and autoimmune and mental disorders (Table 1). Data on the clinicopathological features and hospital complications/case fatality rate of patients with IE are presented in Table 2. The local ethical committee of the Research Institute for Complex Issues of Cardiovascular Diseases approved the study protocol. All the participants provided written informed consent after the study was fully explained.

2.2. SNP Selection and Genotyping. For this study, we defined four main criteria for SNP selection: (1) location within cytokine, acute phase response, hemostasis, lipid metabolism, or calcium metabolism genes; (2) minor allele frequency $\geq 5 \%$ for Russian population tested with HapMap; (3) functional alteration of protein expression; and (4) few or no studies investigating the role of an SNP in IE. The National Center for Biotechnology Information dbSNP, SNPinfo, and SNPnexus databases were utilized for the SNP selection [23, 24]. In total, we selected 35 SNPs within 22 genes (Table 3).

The procedures of DNA extraction and genotyping were the same as previously described [12, 25-27]. Briefly, $5 \mathrm{~mL}$ of venous blood was collected into a tube with ethylenediaminetetraacetic acid. Then, $0.5 \mathrm{~mL}$ of blood was mixed with $1 \mathrm{~mL}$ of saline-sodium citrate buffer (Promega) following centrifugation at $12,000 \mathrm{rpm}$ for $2 \mathrm{~min}$. The pellet was digested in a mixture of $10 \%$ sodium dodecyl sulfate (Sigma) with $100 \mu \mathrm{g} / \mathrm{mL}$ proteinase $\mathrm{K}$ (Helicon) for $3 \mathrm{~h}$ at $50^{\circ} \mathrm{C}$. Upon digestion, we added phenol:chloroform: isoamyl alcohol $(25: 24: 1)$ to the lysate, vortexed it for 20 seconds, and centrifuged at $12,000 \mathrm{rpm}$ for $15 \mathrm{~min} ; 70 \%$ ethanol was further utilized to precipitate genomic DNA from a viscous interphase layer. The sample was finally centrifuged at $12,000 \mathrm{rpm}$ for $5 \mathrm{~min}$. DNA pellet was incubated overnight in deionized water at room temperature and was further stored at $-70^{\circ} \mathrm{C}$ until use.

Genotyping was carried out in a 96-well format using the TaqMan SNP assay on the ViiA ${ }^{\text {TM }} 7$ Real-Time PCR System (Life Technologies) according to the manufacturer's instructions. Amplification mixture contained $100 \mathrm{ng}$ of DNA, $1.25 \mu \mathrm{L}$ of each primer, $2.5 \mathrm{mM}$ of $\mathrm{MgCl} 2,1 \mathrm{mM}$ of dNTPs, and $1 \mathrm{U}$ of Taq polymerase (Life Technologies), in a total volume of $10 \mu \mathrm{L}$. We employed the following polymerase chain reaction (PCR) protocol: hold stage $50^{\circ} \mathrm{C}$ for $120 \mathrm{~s}$ and $95^{\circ} \mathrm{C}$ for $10 \mathrm{~min}$ and PCR stage $95^{\circ} \mathrm{C}$ for $15 \mathrm{~s}$ and $60^{\circ} \mathrm{C}$ for $1 \mathrm{~min}$ repeated in 40 cycles. Table 3 demonstrates the sequencespecific primers for the genotyped SNPs. Laboratory staff was blinded to patient status, and one-tenth of the samples was repeatedly genotyped for quality control purposes. The study workflow is summarized in Figure 1.

2.3. Measurement of Plasma Cytokine Level. Venous blood was withdrawn during hospital admission and 7 days postoperation. The plasma was obtained with a centrifugation for $15 \mathrm{~min}$ at $1780 \times \mathrm{g}$ and $-4^{\circ} \mathrm{C} ; 300 \mu \mathrm{L}$ aliquots have been stored at $-80^{\circ} \mathrm{C}$ until use. The plasma levels of interleukin(IL-) $1 \beta$, IL-6, IL-8, IL-10, IL-12, tumor necrosis factor(TNF-) $\alpha$, and C-reactive protein (CRP) were measured by enzyme-linked immunosorbent assay using the kits purchased from eBioscience (BMS224/2, BMS213/2, BMS204/ 3CE, BMS215/2, BMS238CE, BMS223/4CE, and 88-7502- 
TABLE 2: Characteristics of the patients with infective endocarditis.

Basic characteristics

Type of infective endocarditis

Native (93/123, 75.61\%)

Prosthetic (30/123, 24.39\%)

Device (0/123, 0.0\%)
Location

Left-sided (116/123, 94.31\%)

Right-sided (6/123, 4.88\%)

Double-sided (1/123, 0.81\%)

Echocardiography characteristics (mean \pm standard deviation)

Left atrial diameter, $\mathrm{cm}$

Left ventricular end-diastolic diameter, $\mathrm{cm}$

Left ventricular end-systolic diameter, $\mathrm{cm}$

Left ventricular end-diastolic volume, $\mathrm{cm}^{3}$

Left ventricular end-systolic volume, $\mathrm{cm}^{3}$

Interventricular septal thickness, $\mathrm{cm}$

Left ventricular posterior wall thickness, $\mathrm{cm}$

Left ventricular ejection fraction, \%

Right atrial diameter, $\mathrm{cm}$

Right ventricular diameter, $\mathrm{cm}$

Hospital complications

Hydrothorax

Pneumonia

Multiple organ dysfunction syndrome

Arrhythmia

Heart block

Heart failure

Myocardial infarction

Stroke

Hospital case fatality rate

Death

$$
\begin{gathered}
4.78 \pm 0.90 \\
6.01 \pm 1.17 \\
3.92 \pm 0.76 \\
207.80 \pm 93.98 \\
72.13 \pm 36.05 \\
1.06 \pm 0.18 \\
1.07 \pm 0.19 \\
64.00 \pm 7.64 \\
5.20 \pm 1.19 \\
2.51 \pm 1.08 \\
\\
32 / 123(26.02 \%) \\
21 / 123(17.07 \%) \\
17 / 123(13.82 \%) \\
33 / 123(26.83 \%) \\
7 / 123(5.69 \%) \\
46 / 123(37.40 \%) \\
4 / 123(3.25 \%) \\
2 / 123(1.63 \%) \\
1 / 123(0.81 \%)
\end{gathered}
$$

28, resp.) according to the manufacturer's instructions. All samples were plated in duplicates, with average concentrations used for further analysis.

2.4. Statistical Analysis. The statistical analysis was performed as in [12, 25-27] using GraphPad Prism (GraphPad Software) and SNPStats, a web tool for the analysis of genetic association studies [28].

\section{Results}

Here, we evaluated the distribution of SNPs within 22 core genes involved in cytokine activity, acute phase response, lipid metabolism, and calcium metabolism genes in a sample of 123 patients with IE and 300 matched asymptomatic control individuals (Table 3 ). Tables 1 and 2 summarize demographic and clinicopathological characteristics of cases and controls. We did not find statistically significant gender differences between the groups (Table 1). The genotype distributions in both groups are presented in Table 4. All the genotype distributions were in Hardy-Weinberg equilibrium that confirmed a good quality of the genotyping.
We first asked whether an inherited variation within the genes encoding cytokines and acute phase proteins may play a role in the risk of IE development. Having performed the genetic association analysis with the adjustments for age and gender, we found that the G/A genotype of the rs1143634 polymorphism within the IL1B gene was associated with a lower risk of $\mathrm{IE}(\mathrm{OR}=0.43,95 \% \mathrm{CI}=0.26-0.71$, $p=0.0016$, overdominant model, Table 4). Similarly, the G/T genotype of the rs3212227 polymorphism within the IL $12 B$ gene correlated with a decreased risk of IE (OR $=0.57,95 \% \mathrm{CI}=0.34-0.94, p=0.0250$, overdominant model, Table 4). Finally, we observed that the A/G genotype of the rs1130864 polymorphism within the CRP gene was also associated with a lower risk of IE $(\mathrm{OR}=0.54,95 \%$ $\mathrm{CI}=0.34-0.86, p=0.0083$, overdominant model, Table 4). Conversely, the T/T genotype of the rs1205 polymorphism within the CRP gene was associated with a higher risk of IE $(\mathrm{OR}=2.42,95 \% \mathrm{CI}=1.32-4.43, p=0.0047$ according to a recessive model, Table 4). Other SNPs were not significantly different between cases and controls (Table 4).

We further investigated whether the inherited variation in the pathways of hemostasis, lipid metabolism, and calcium metabolism can be linked to IE. The A/G genotype of the 
TABLE 3: Features of the gene polymorphisms used in the study.

\begin{tabular}{|c|c|c|c|c|}
\hline $\begin{array}{l}\text { Single nucleotide } \\
\text { polymorphism }\end{array}$ & $\begin{array}{l}\text { Nucleotide } \\
\text { substitution }\end{array}$ & $\begin{array}{l}\text { Chromosomal } \\
\text { position }\end{array}$ & $\begin{array}{l}\text { Amino acid } \\
\text { substitution }\end{array}$ & $\begin{array}{c}\text { Forward } 5^{\prime}-3^{\prime} \text { and reverse } 3^{\prime}-5^{\prime} \text { polymerase chain } \\
\text { reaction primers }\end{array}$ \\
\hline \multicolumn{5}{|l|}{ IL1B gene } \\
\hline rs1143634 & $\mathrm{G}>\mathrm{A}$ & 113590390 & Phe105Phe & $\begin{array}{l}\text { F: cataagcctcgttatcccatgtgtc } \\
\text { R: aagaagataggttctgaaatgtgga }\end{array}$ \\
\hline \multicolumn{5}{|l|}{ IL6 gene } \\
\hline rs1554606 & $\mathrm{T}>\mathrm{G}$ & 22768707 & Intronic & $\begin{array}{l}\text { F: ttagttcatcctgggaaaggtactc } \\
\text { R: cagggccttttccctctctggctgc }\end{array}$ \\
\hline rs1800796 & $\mathrm{G}>\mathrm{C}$ & 22766246 & $5^{\prime}$-upstream & $\begin{array}{l}\text { F: atggccaggcagttctacaacagcc } \\
\text { R: ctcacagggagagccagaacacaga }\end{array}$ \\
\hline rs2069827 & $\mathrm{G}>\mathrm{T}$ & 22765456 & $5^{\prime}$-upstream & $\begin{array}{l}\text { F: gcccaacagaggtcactgttttatc } \\
\text { R: atcttgaagagatctcttcttagca }\end{array}$ \\
\hline \multicolumn{5}{|l|}{ IL6R gene } \\
\hline rs2228145 & $\mathrm{A}>\mathrm{T} / \mathrm{C}$ & 154426970 & Asp358Val/Ala & $\begin{array}{l}\text { F: aattttttttttaacctagtgcaag } \\
\text { R: ttcttcttcagtaccactgcccaca }\end{array}$ \\
\hline rs2229238 & $\mathrm{T}>\mathrm{C}$ & 154437896 & 3'-UTR & $\begin{array}{l}\text { F: ccagcagcctggaccctgtggatga } \\
\text { R: aaaacacaaacgggctcagcaaaag }\end{array}$ \\
\hline \multicolumn{5}{|l|}{ IL8 gene } \\
\hline rs2227306 & $\mathrm{C}>\mathrm{T}$ & 74607055 & Intronic & $\begin{array}{l}\text { F: aactctaactctttatataggaagt } \\
\text { R: gttcaatgttgtcagttatgactgt }\end{array}$ \\
\hline \multicolumn{5}{|l|}{ IL10 gene } \\
\hline rs 1800871 & $A>G$ & 206946634 & $5^{\prime}$-upstream & $\begin{array}{l}\text { F: agtgagcaaactgaggcacagagat } \\
\text { R: ttacatcacctgtacaagggtacac }\end{array}$ \\
\hline rs1800872 & $\mathrm{T}>\mathrm{G}$ & 206946407 & $5^{\prime}$-upstream & $\begin{array}{l}\text { F: ttttactttccagagactggcttcctacag } \\
\text { R: acaggcggggtcacaggatgtgttccaggc }\end{array}$ \\
\hline rs1800896 & $\mathrm{T}>\mathrm{C}$ & 206946897 & 5'-upstream & $\begin{array}{l}\text { F: tcctcttacctatccctacttcccc } \\
\text { R: tcccaaagaagccttagtagtgttg }\end{array}$ \\
\hline \multicolumn{5}{|l|}{ IL12B gene } \\
\hline rs3212227 & $\mathrm{T}>\mathrm{G}$ & 158742950 & 3'-UTR & $\begin{array}{l}\text { F: attgtttcaatgagcatttagcatc } \\
\text { R: aactatacaaatacagcaaagatat }\end{array}$ \\
\hline \multicolumn{5}{|l|}{ IL12RB gene } \\
\hline rs375947 & $A>G$ & 18180451 & Met365Thr & $\begin{array}{l}\text { F: aggctgccattcaatgcaatacgtc } \\
\text { R: tgctctgagcccgggctggccaata }\end{array}$ \\
\hline \multicolumn{5}{|l|}{ TNF gene } \\
\hline rs361525 & $\mathrm{G}>\mathrm{A}$ & 31543101 & 5'-upstream & $\begin{array}{l}\text { F: ggcccagaagacccccctcggaatc } \\
\text { R: gagcagggaggatggggagtgtgag }\end{array}$ \\
\hline rs1800629 & $\mathrm{G}>\mathrm{A}$ & 31543031 & 5'-upstream & $\begin{array}{l}\text { F: gaggcaataggttttgaggggcatg } \\
\text { R: ggacggggttcagcctccagggtcc }\end{array}$ \\
\hline \multicolumn{5}{|l|}{$C R P$ gene } \\
\hline rs3093077 & $\mathrm{A}>\mathrm{C}$ & 159679636 & Not announced & $\begin{array}{l}\text { F: ggaatccaggcaagtacgacaaccc } \\
\text { R: tctgagactagtgggcagttgtcct }\end{array}$ \\
\hline rs1130864 & $\mathrm{G}>\mathrm{A}$ & 159683091 & 3'-UTR & $\begin{array}{l}\text { F: cctcaaattctgattcttttggacc } \\
\text { R: tttcccagcatagttaacgagctcc }\end{array}$ \\
\hline rs1205 & $\mathrm{C}>\mathrm{T}$ & 159682233 & 3'-UTR & $\begin{array}{l}\text { F: acttccagtttggcttctgtcctca } \\
\text { R: agtctctctccatgtggcaaacaag }\end{array}$ \\
\hline \multicolumn{5}{|l|}{$A P O B$ gene } \\
\hline rs1042031 & $\mathrm{C}>\mathrm{T}$ & 21225753 & Glu4181Lys & $\begin{array}{l}\text { F: caatcagatgcttgactttcatatggaatt } \\
\text { R: ttgagtaactcgtaccaagccatcaaacac }\end{array}$ \\
\hline rs6725189 & $\mathrm{G}>\mathrm{T}$ & 21219001 & Not announced & $\begin{array}{l}\text { F: ttcccagcctcagctcaacagagctatggg } \\
\text { R: cagcagtcggecctctctattgttctttcc }\end{array}$ \\
\hline \multicolumn{5}{|l|}{$A P O E$ gene } \\
\hline rs7412 & $\mathrm{C}>\mathrm{T}$ & 45412079 & Arg176Cys & $\begin{array}{l}\text { F: ctcctccgcgatgccgatgacctgcagaag } \\
\text { R: gcctggcagtgtaccaggccggggeccgcg }\end{array}$ \\
\hline
\end{tabular}


TABLE 3: Continued.

\begin{tabular}{|c|c|c|c|c|}
\hline $\begin{array}{l}\text { Single nucleotide } \\
\text { polymorphism }\end{array}$ & $\begin{array}{l}\text { Nucleotide } \\
\text { substitution }\end{array}$ & $\begin{array}{l}\text { Chromosomal } \\
\text { position }\end{array}$ & $\begin{array}{l}\text { Amino acid } \\
\text { substitution }\end{array}$ & $\begin{array}{c}\text { Forward } 5^{\prime}-3^{\prime} \text { and reverse } 3^{\prime}-5^{\prime} \text { polymerase chain } \\
\text { reaction primers }\end{array}$ \\
\hline rs429358 & $\mathrm{T}>\mathrm{C}$ & 45411941 & Cys130Arg & $\begin{array}{l}\text { F: gcccggctgggcgcggacatggaggacgtg } \\
\text { R: gcggccgcctggtgcagtaccgcggcgagg }\end{array}$ \\
\hline \multicolumn{5}{|l|}{ LIPC gene } \\
\hline rs 1800588 & $\mathrm{C}>\mathrm{T}$ & 58723675 & $5^{\prime}$-upstream & $\begin{array}{l}\text { F: tctttgcttcttcgtcagctccttttgaca } \\
\text { R: gggggtgaagggttttctgcaccacacttt }\end{array}$ \\
\hline \multicolumn{5}{|l|}{$L P A$ gene } \\
\hline rs10455872 & $A>G$ & 161010118 & Intronic & $\begin{array}{l}\text { F: tcagacaccttgttctcagaaccca } \\
\text { R: tgtgtttatacaggttagaggagaa }\end{array}$ \\
\hline \multicolumn{5}{|l|}{ NOTCH1 gene } \\
\hline rs13290979 & $A>G$ & 139425634 & Intronic & $\begin{array}{l}\text { F: ccagcccagcagtgaagaaactgagcccac } \\
\text { R: accctcctggectgacctacactcgggctt }\end{array}$ \\
\hline \multicolumn{5}{|l|}{$V D R$ gene } \\
\hline rs2228570 & $A>G$ & 48272895 & Met1Thr/Lys/Arg & $\begin{array}{l}\text { F: ggcagggaagtgctggccgccattgcctcc } \\
\text { R: tccctgtaagaacagcaagcaggccacggt }\end{array}$ \\
\hline \multicolumn{5}{|l|}{ CASR gene } \\
\hline rs1042636 & $A>G$ & 122003769 & Arg990Gly & $\begin{array}{l}\text { F: gatgagcctcagaagaacgccatggcccac } \\
\text { R: ggaattctacgcaccagaactccetggagg }\end{array}$ \\
\hline \multicolumn{5}{|l|}{$O P G$ gene } \\
\hline rs3134069 & $\mathrm{A}>\mathrm{C}$ & 119964988 & $5^{\prime}$-upstream & $\begin{array}{l}\text { F: ggagcttcctacgcgctgaacttctggagt } \\
\text { R: gcctcctcgaggtctttccactagcctcaa }\end{array}$ \\
\hline rs2073618 & $\mathrm{G}>\mathrm{C}$ & 119964052 & Asn3Lys & $\begin{array}{l}\text { F: gggacttaccacgagcgcgcagcacagcaa } \\
\text { R: ttgttcattgtggtccccggaaacctcagg }\end{array}$ \\
\hline rs3102735 & $\mathrm{T}>\mathrm{C}$ & 119965070 & 5-upstream & $\begin{array}{l}\text { F: ctttgctctagggttcgctgtctcccccat } \\
\text { R: aattccctggtctagaagttagacttgatg }\end{array}$ \\
\hline \multicolumn{5}{|l|}{$C A L C R$ gene } \\
\hline rs1801197 & $A>G$ & 93055753 & Leu481Pro & $\begin{array}{l}\text { F: tcgccttggttgttggctggttcattcctc } \\
\text { R: gctcctgatggcagatgtaaattgggatgt }\end{array}$ \\
\hline \multicolumn{5}{|l|}{ F2 gene } \\
\hline rs1799963 & $\mathrm{G}>\mathrm{A}$ & 46761055 & 3'-UTR & $\begin{array}{l}\text { F: gttcccaataaaagtgactctcagc } \\
\text { R: agcctcaatgctcccagtgctattc }\end{array}$ \\
\hline \multicolumn{5}{|l|}{ F5 gene } \\
\hline rs6025 & $\mathrm{T}>\mathrm{C}$ & 169519049 & Gln534Arg & $\begin{array}{l}\text { F: ttacttcaaggacaaaatacctgtattcct } \\
\text { R: gcctgtccagggatctgctcttacagatta }\end{array}$ \\
\hline rs6027 & $\mathrm{T}>\mathrm{C}$ & 169483561 & Asp2222Gly & $\begin{array}{l}\text { F: gggtttttgaatgttcaattctagtaaata } \\
\text { R: cacagccaaagagttccaggcgaagtgcaa }\end{array}$ \\
\hline \multicolumn{5}{|l|}{ F7 gene } \\
\hline rs6046 & $\mathrm{G}>\mathrm{A}$ & 113773159 & $\begin{array}{l}\text { Arg412Gln/Pro/ } \\
\text { Leu }\end{array}$ & $\begin{array}{l}\text { F: acagtggaggcccacatgccacccactacc } \\
\text { R: gggcacgtggtacctgacgggcatcgtcag }\end{array}$ \\
\hline \multicolumn{5}{|l|}{ ITGB3 gene } \\
\hline rs5918 & $\mathrm{T}>\mathrm{C}$ & 45360730 & Leu59Pro & $\begin{array}{l}\text { F: tttgggctcctgacttacaggccctgcctc } \\
\text { R: gggctcacctcgctgtgacctgaaggagaa }\end{array}$ \\
\hline
\end{tabular}

IL: interleukin; TNF: tumor necrosis factor; CRP: C-reactive protein; APO: apolipoprotein; LIPC: hepatic lipase; LPA: lipoprotein (a); VDR: vitamin D receptor; CASR: calcium-sensing receptor; OPG: osteoprotegerin; CALCR: calcitonin receptor; ITGB: integrin beta.

rs13290979 polymorphism within the NOTCH1 gene and the $\mathrm{G}$ allele of the rs1801197 polymorphism within the CALCR gene were associated with a lower risk of $\mathrm{IE}(\mathrm{OR}=0.54$, 95\% CI $=0.34-0.84, p=0.0062$ according to an overdominant model; $\mathrm{OR}=0.56,95 \% \mathrm{CI}=0.38-0.82, p=0.0020$ according to a log-additive model, resp., Table 4). Other SNPs were not significantly associated with IE (Table 4).

As cytokines are easily detected in blood, we then sought to explore the functional consequences of four
SNPs reaching the significance threshold in IL1B, IL12, and CRP genes. We evaluated the plasma levels of these proteins obtained from the patients with IE before admission and 7 days postoperation (Figure 2). The G/A genotype of the rs1143634 polymorphism within the IL1B gene and the G/T genotype of the rs3212227 polymorphism within the IL12B gene were associated with a higher plasma level of IL-1 $\beta$ and IL-12, respectively, at either time point (Figure 2). However, no significant associations were revealed for CRP 


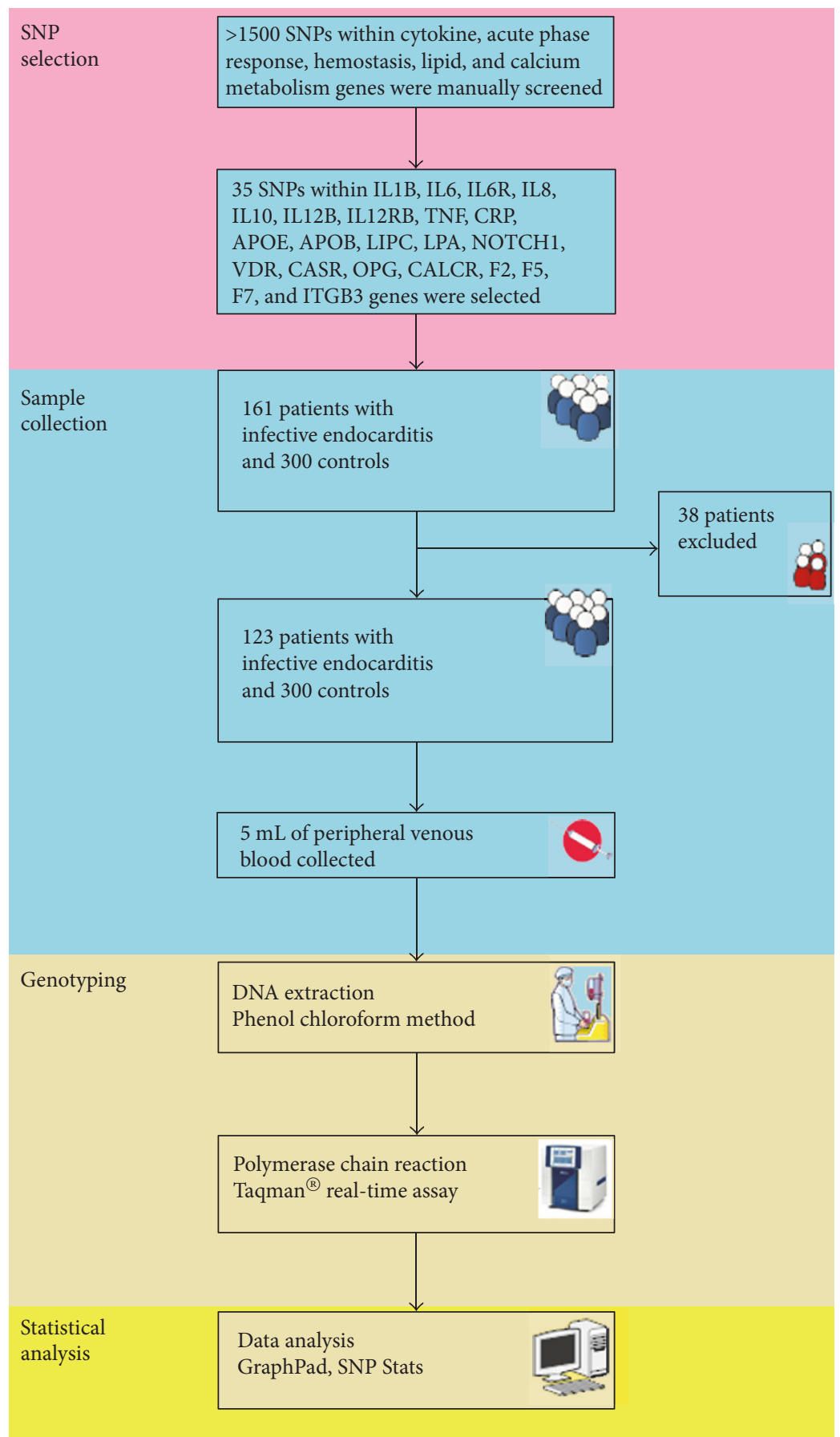

FIgURE 1: Study workflow.

(Figure 2). To further reinforce the associations between the marker SNPs, plasma cytokine levels, and risk of IE, we hypothesized that those SNPs which did not demonstrate a predictive value would not show associations with altered plasma levels of the corresponding proteins. Hence, we performed the similar analysis for the SNPs within the genes encoding cytokines which are generally elevated in patients with IE, that is, TNF- $\alpha$, IL-6, IL-8, and IL-10 (Supplementary Figures 1 and 2 available online at https://doi.org/10.1155/ 2017/7962546). Expectedly, no statistically significant associations were found.

\section{Discussion}

Despite the recent progress in diagnosis and treatment $[1,2]$, the basis of genetic susceptibility to IE remains vaguely uncovered. Early investigation by Vollmer et al. revealed the $G$ allele of the rs 2232596 polymorphism and the $T$ allele of the rs2232582 polymorphism within the $L B P$ gene being associated with a higher risk of IE [29]. As known, lipopolysaccharide-binding protein is released into the bloodstream as an acute phase response protein during IE [19]. Further studies by Daga et al. [30, 31] and Durante- 


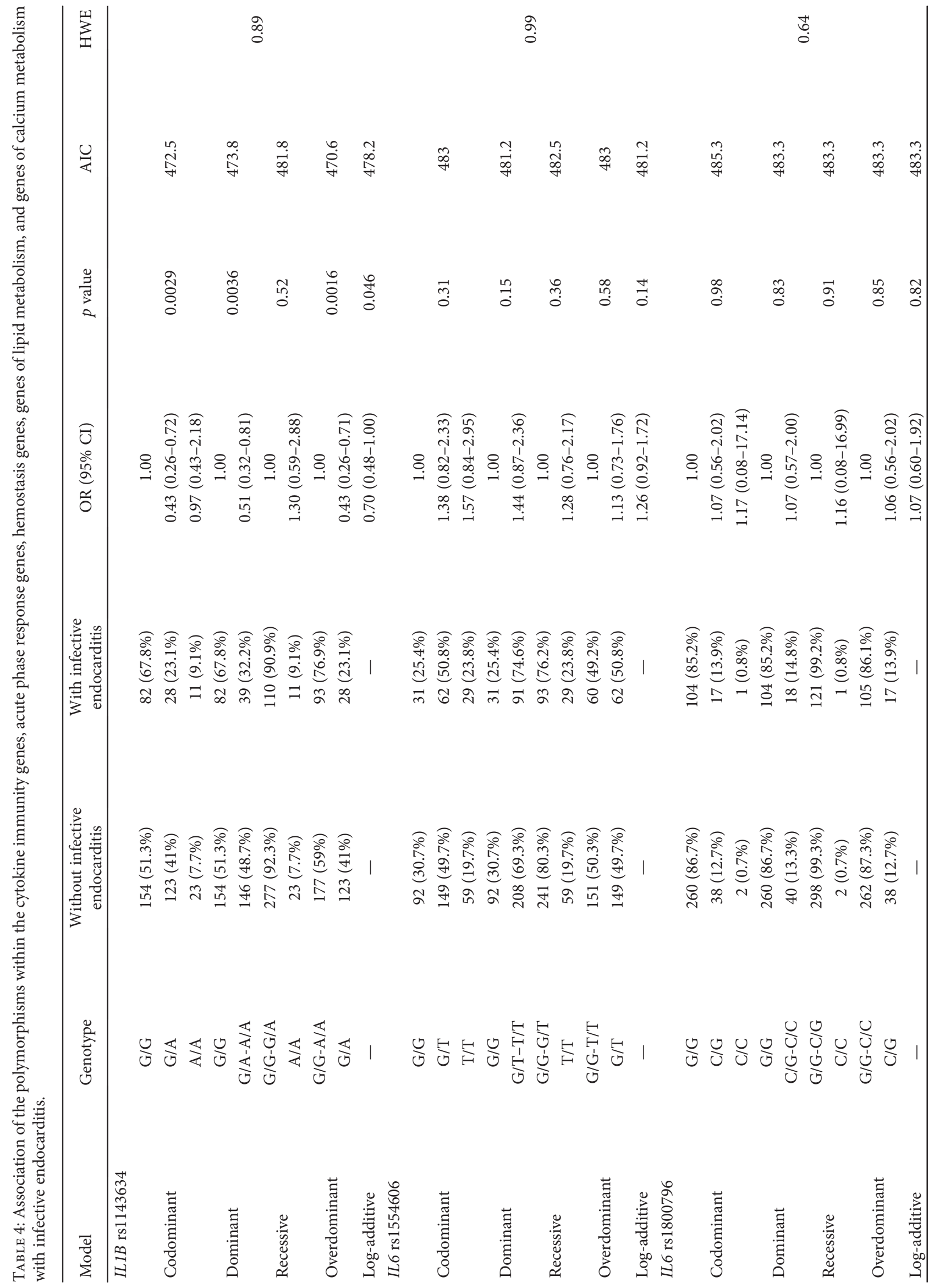




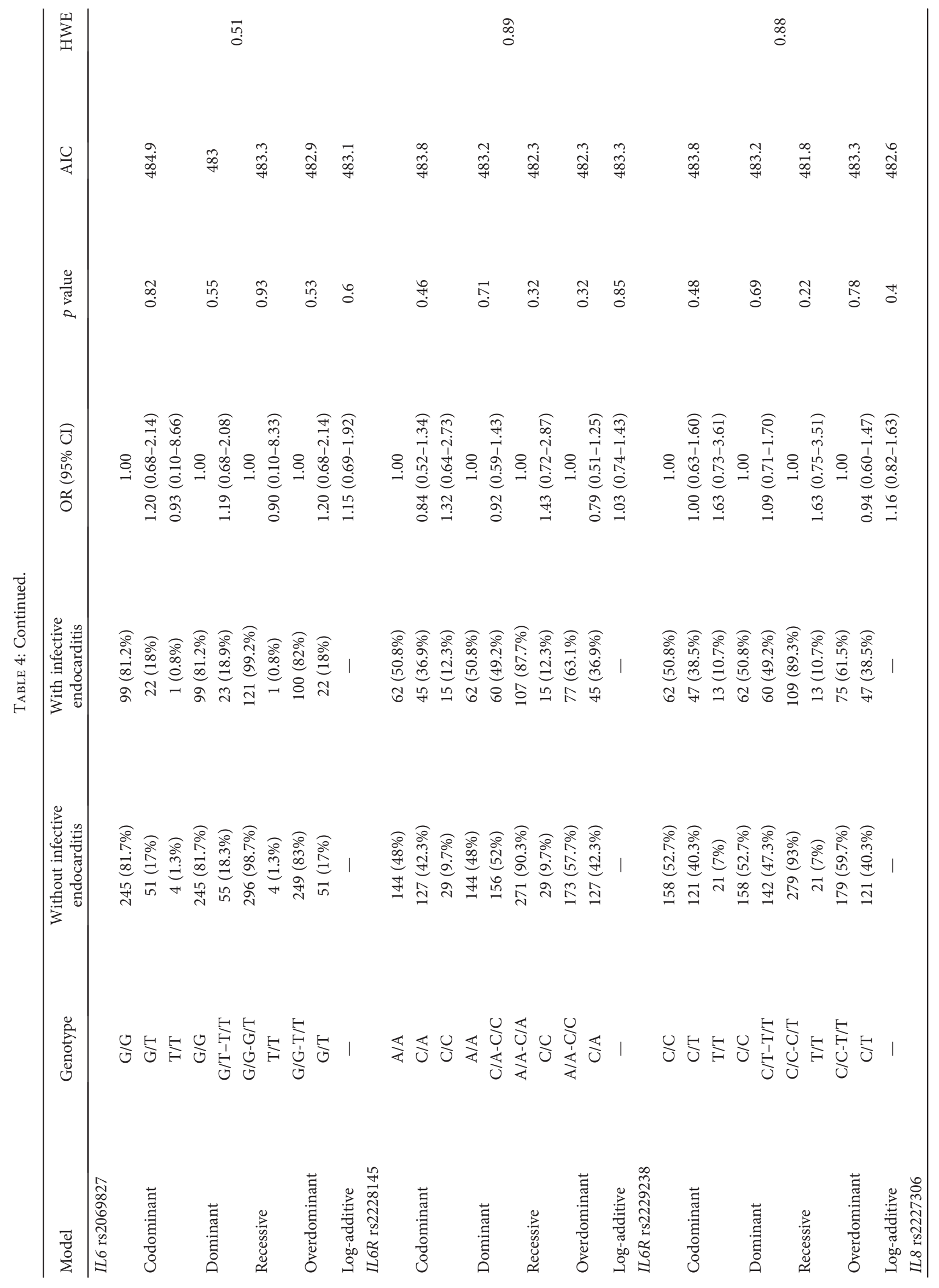




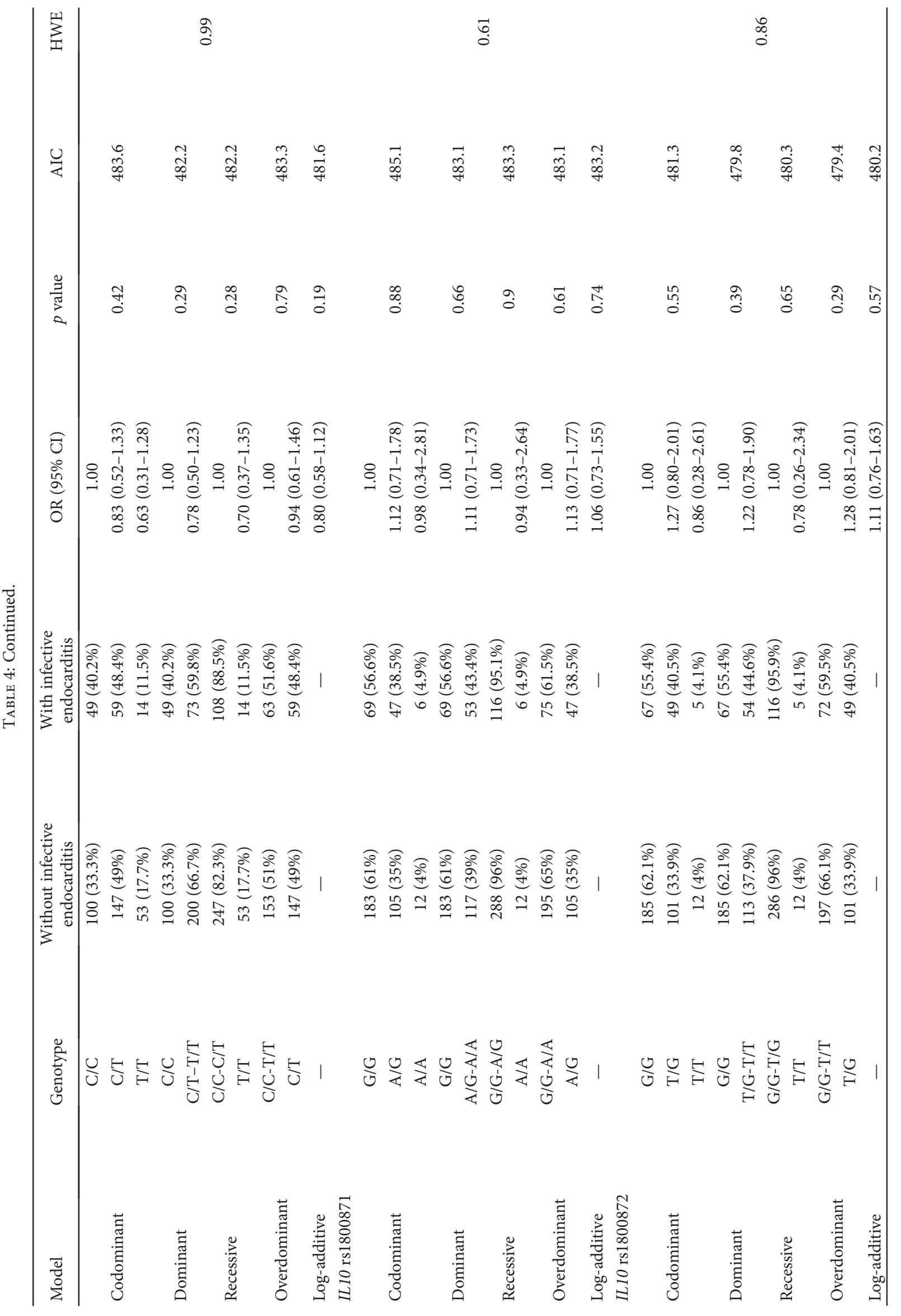




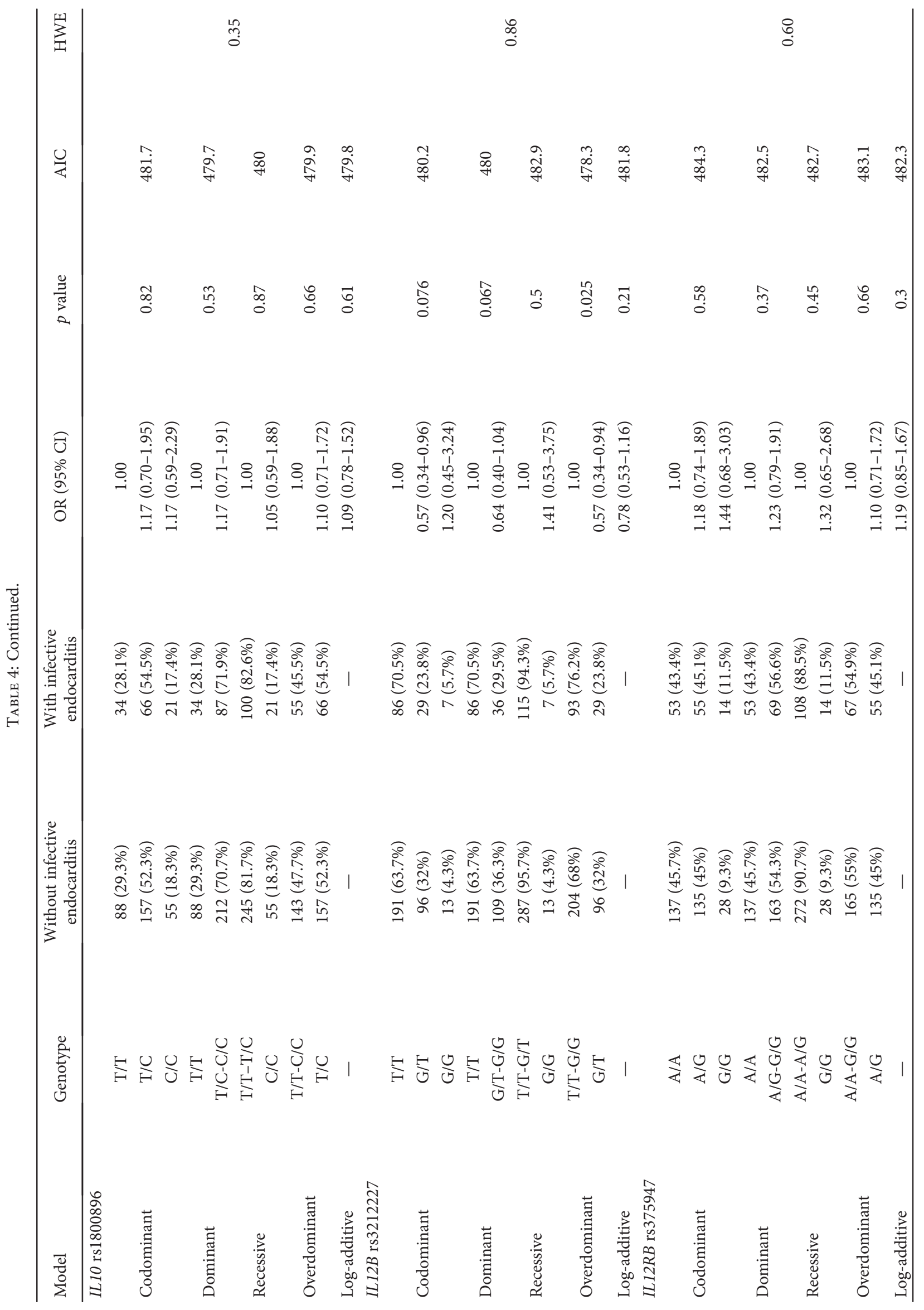




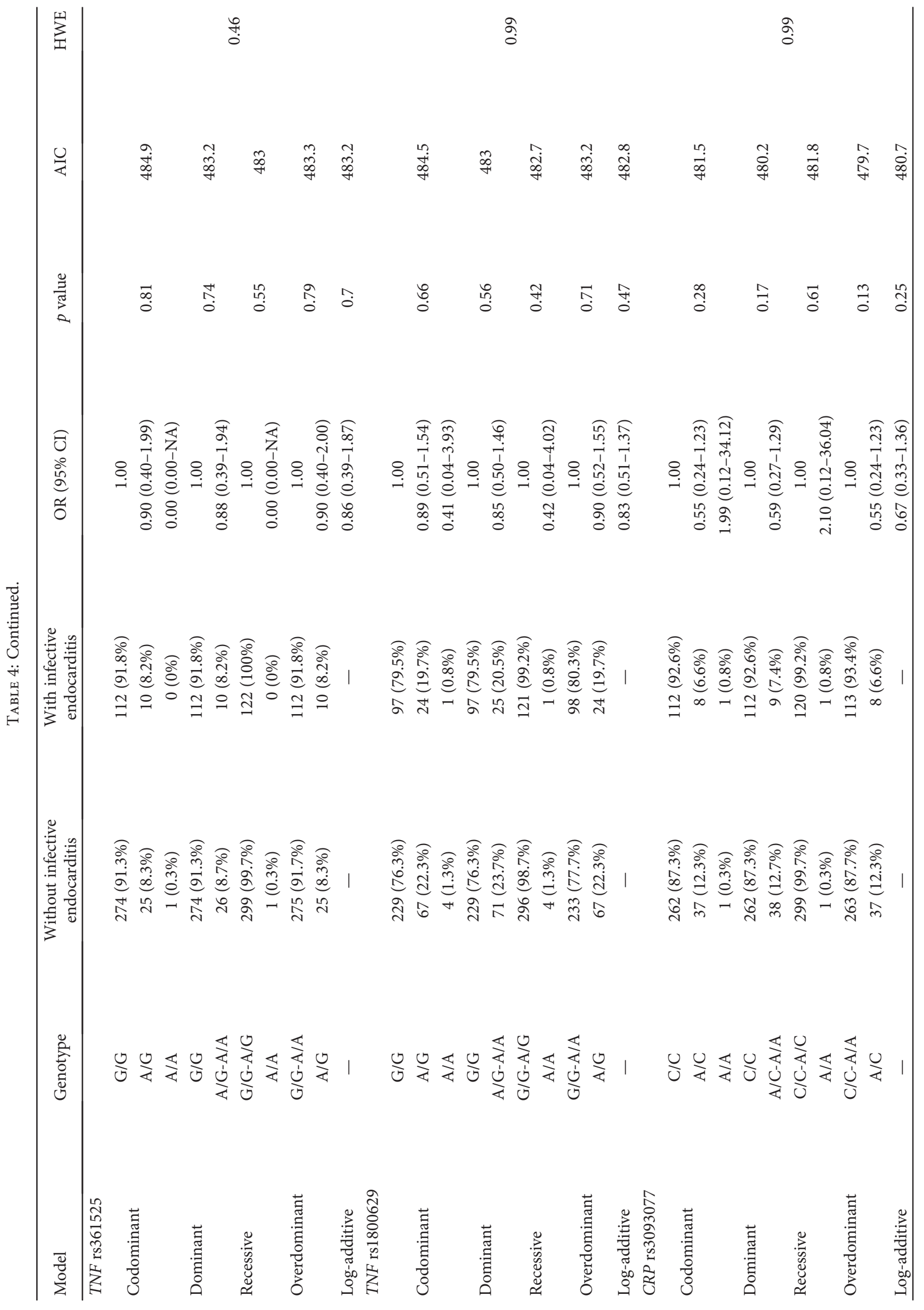




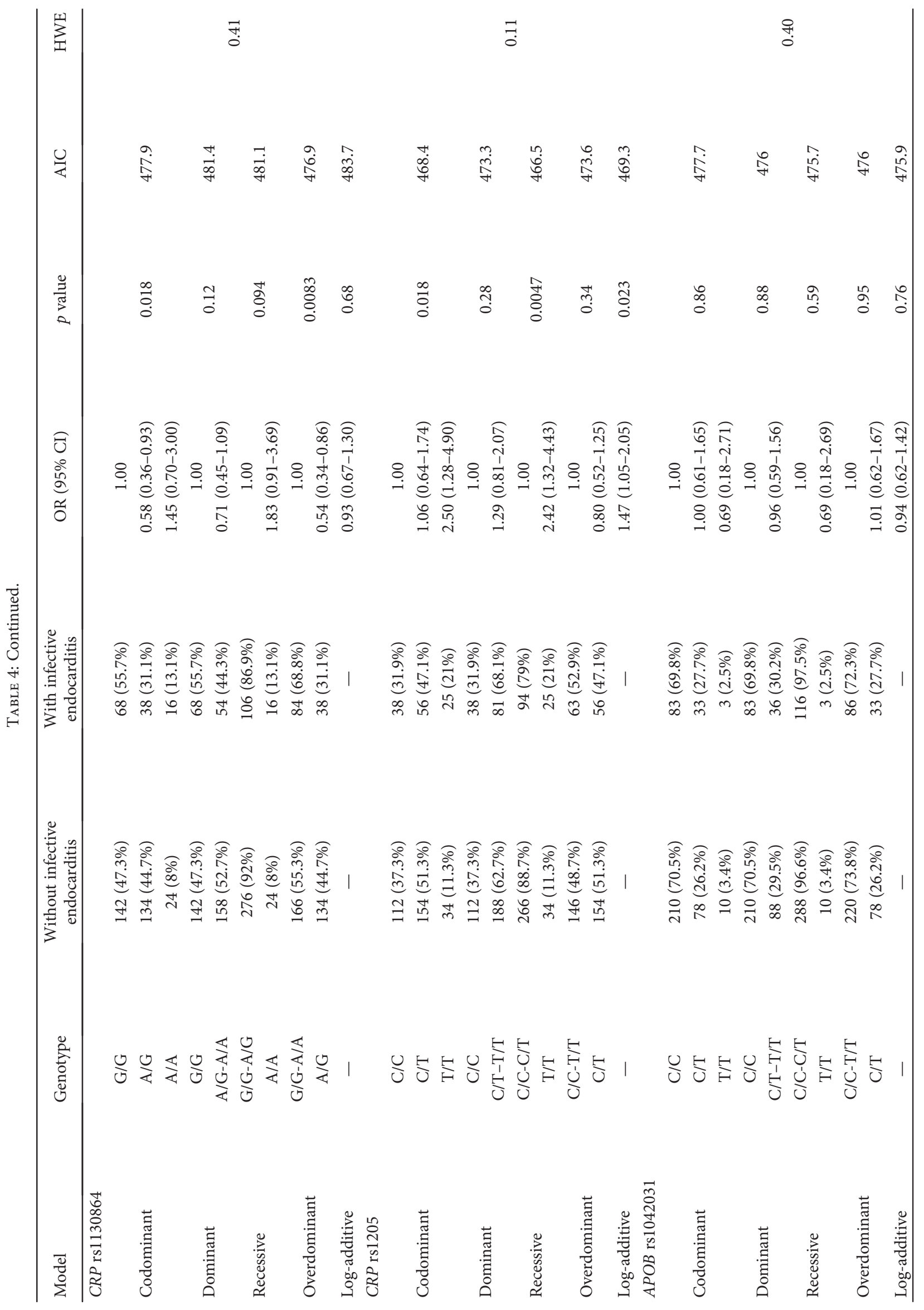




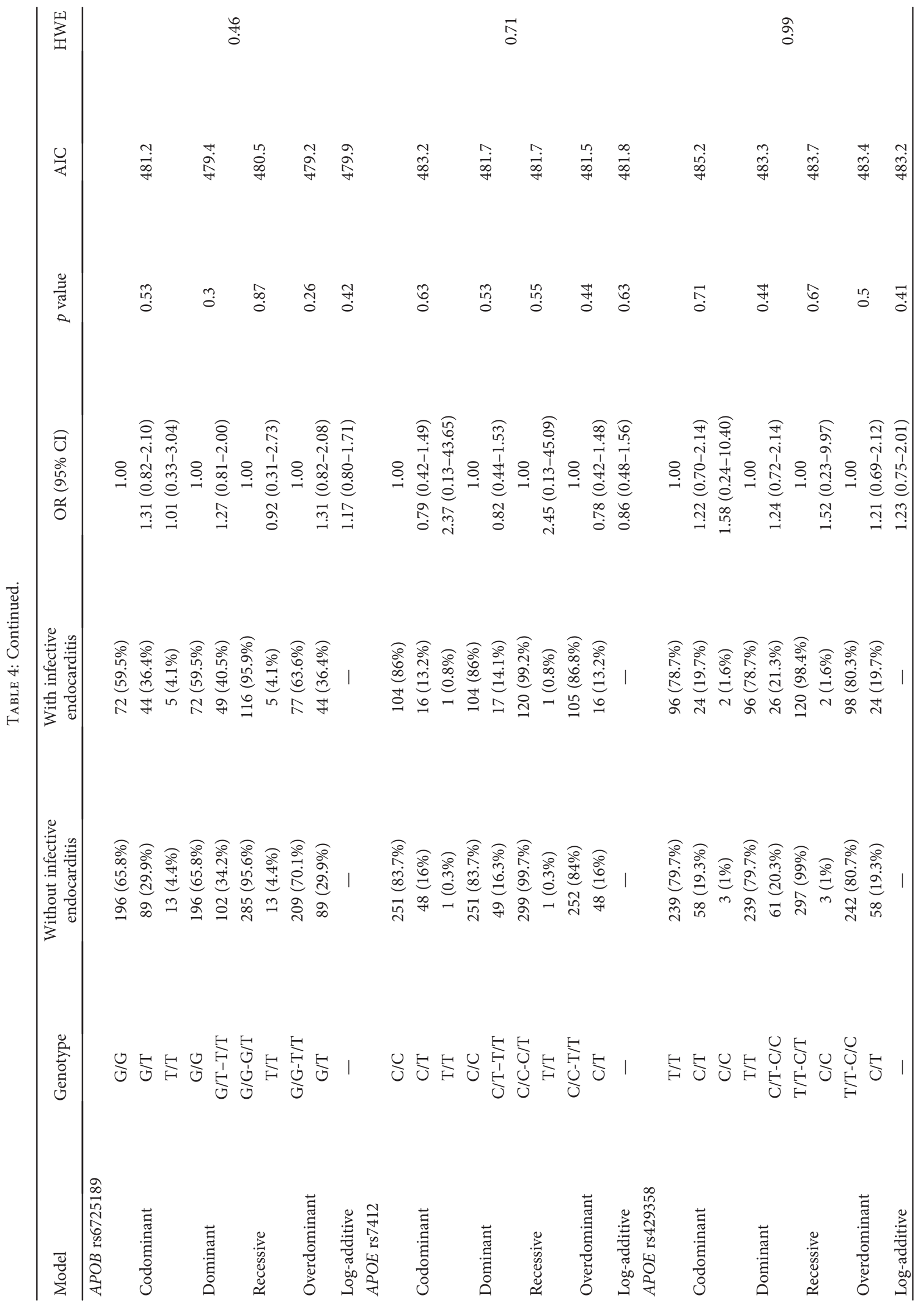




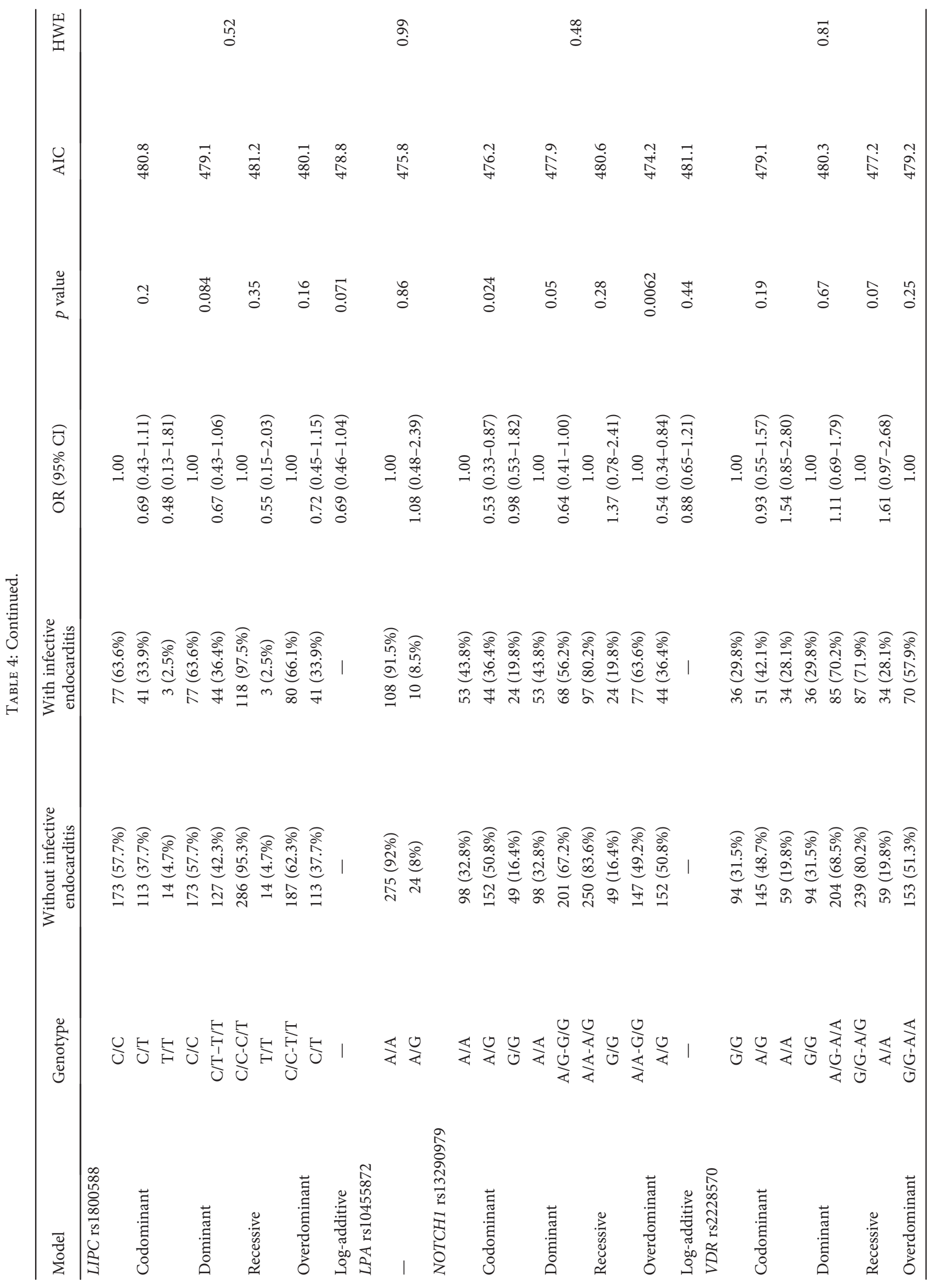




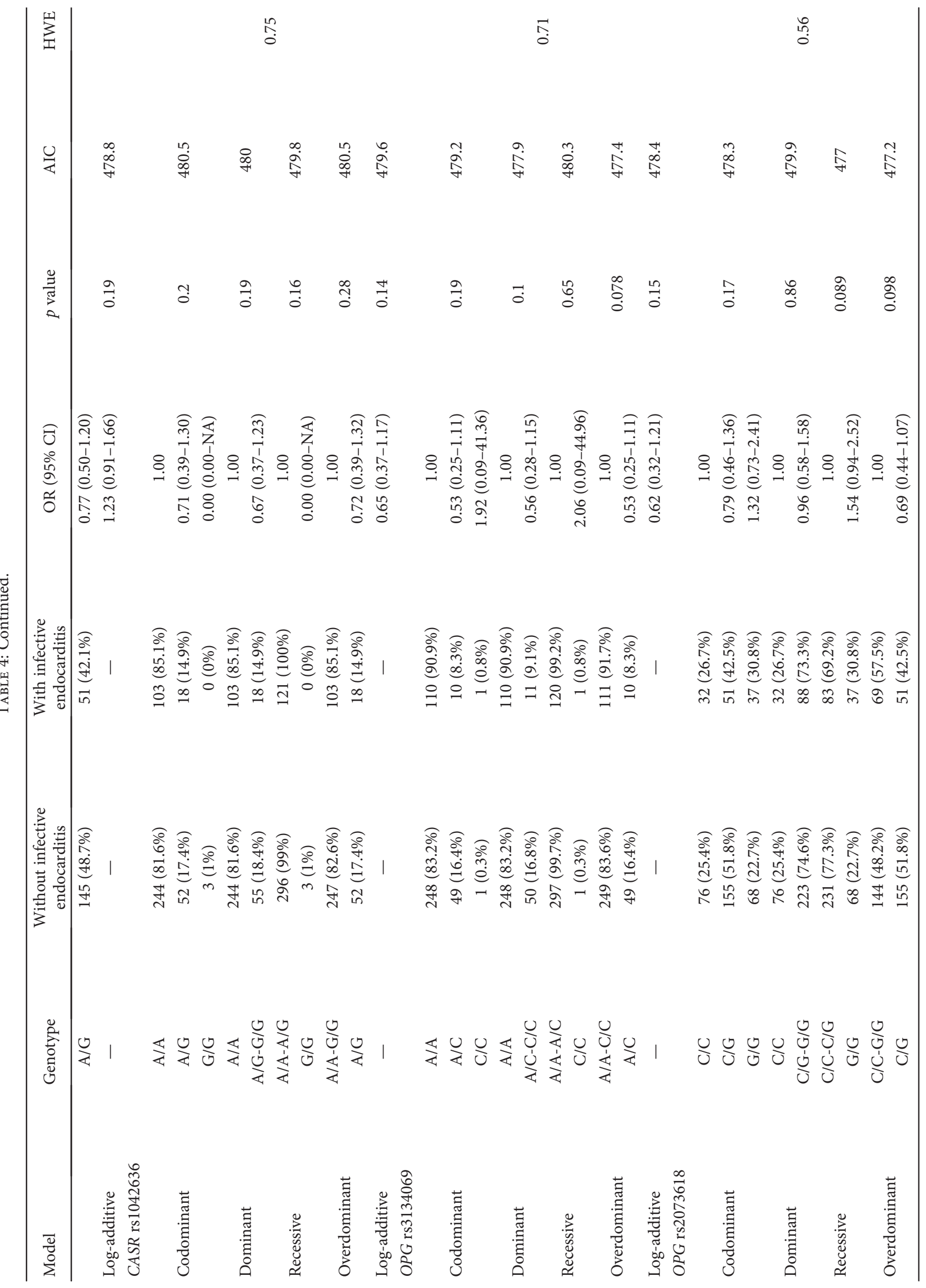




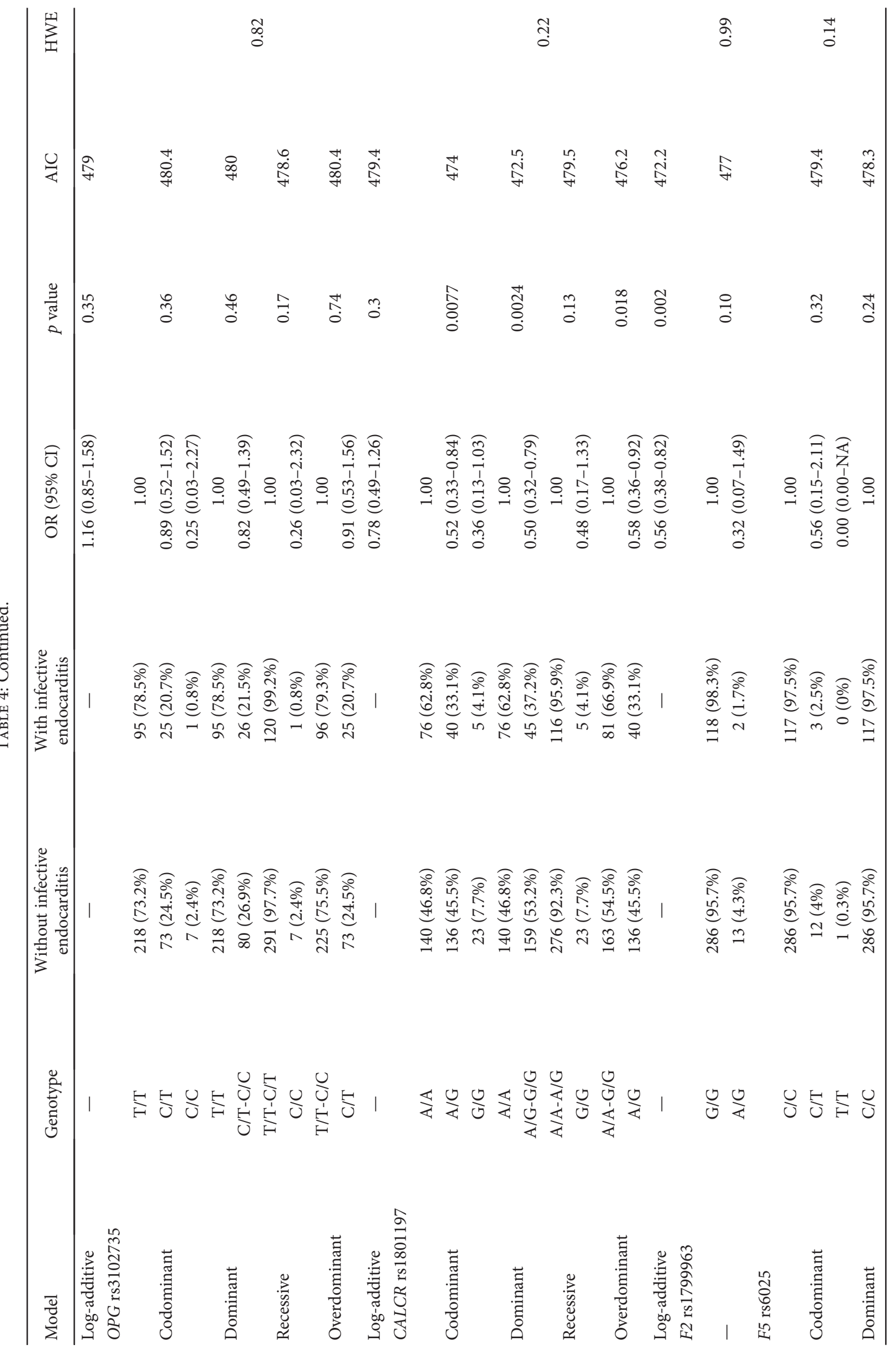




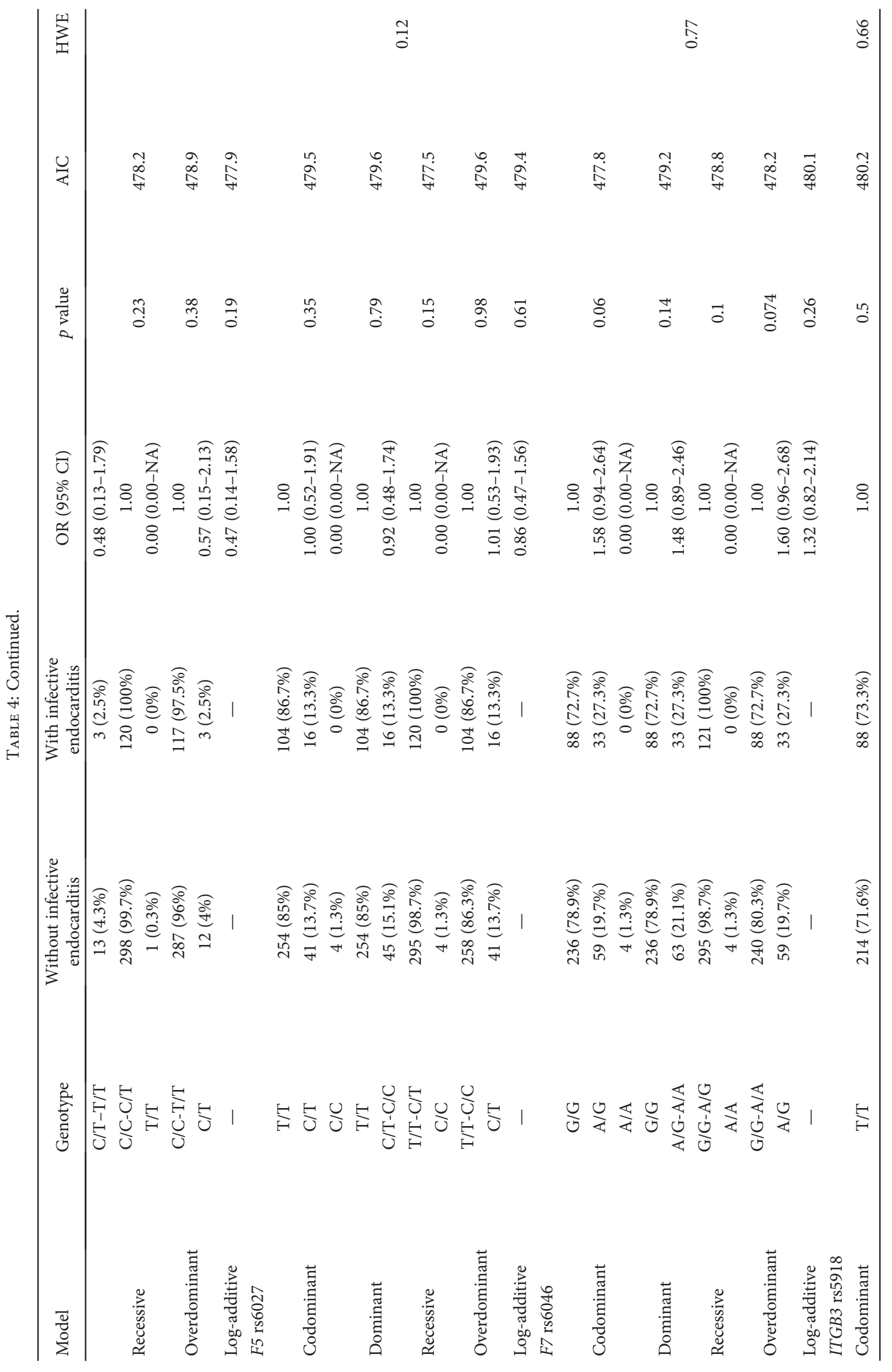




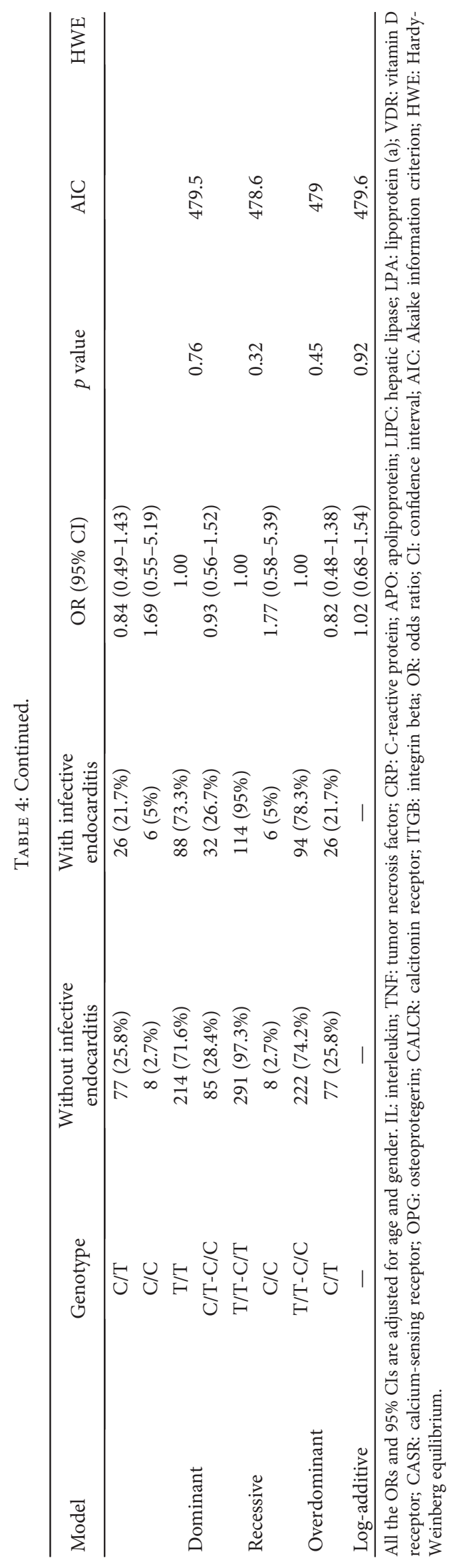




\begin{tabular}{cccc} 
Interleukin-1 $\beta$ & Interleukin-12 & C-reactive protein \\
\hline $\operatorname{rs} 1143634$ & rs3212227 & rs1130864 & rs1205 \\
\hline
\end{tabular}
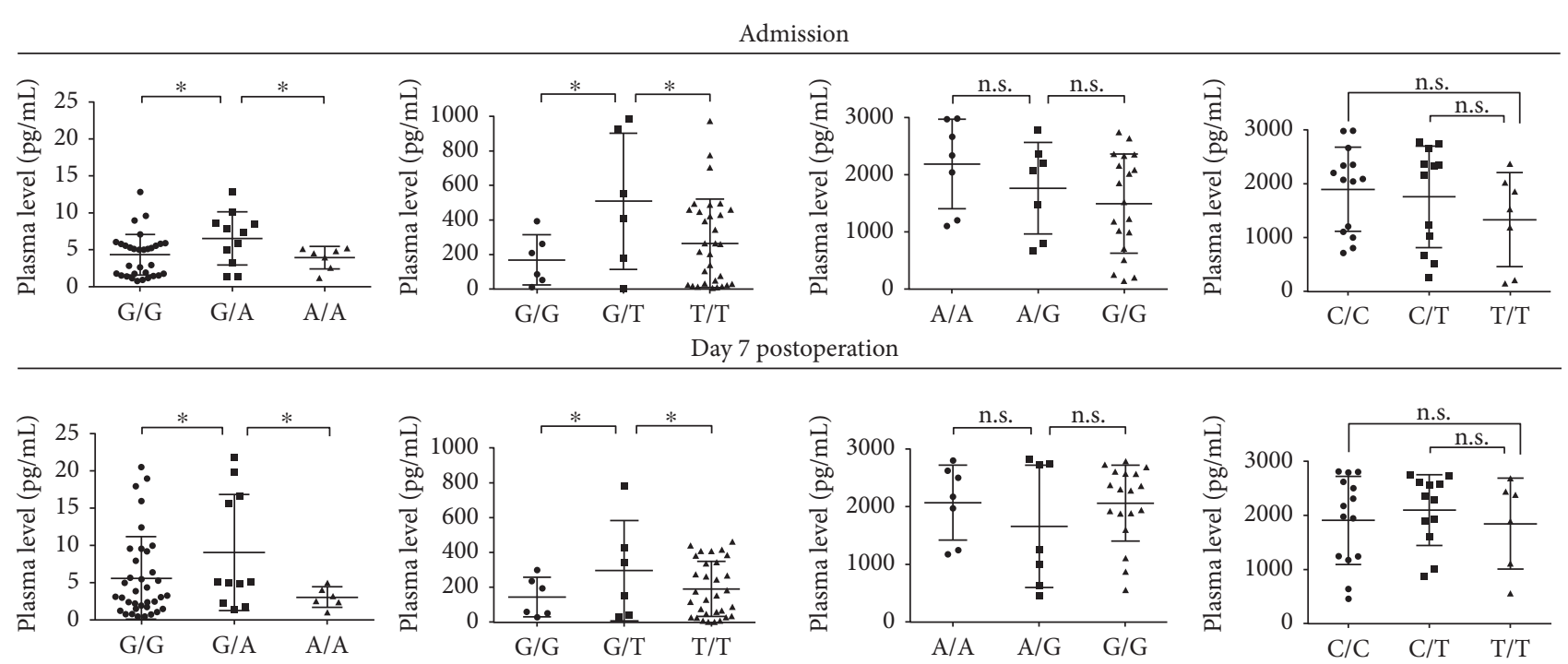

FIGURE 2: Measurement of plasma interleukin-1 $\beta$, interleukin-12, and C-reactive protein levels in patients with infective endocarditis at the hospital admission and 7 days postoperation. Two-tailed Student's $t$-test with further Tukey's post hoc test to adjust for multiple comparisons; each dot is a measure from one patient, ${ }^{*} p<0.05$, n.s. is for not significant.

Mangoni et al. [32] did not find any association between the SNPs within the hemostasis genes (PTH, FV, GPIb, GPIIIa, and $F c \gamma R I I a$ ) and IE. Our previous study identified the $\mathrm{C} / \mathrm{C}$ genotype of the rs3775073 polymorphism within the TLR6 gene as a protective factor [12] while a study by Bustamante et al. suggested the A allele of the rs5743708 polymorphism within the TLR2 gene as a risk factor [33]. In this study, we selected 35 SNPs within 22 genes involved in the development of IE: IL1B, IL6, IL6R, IL8, IL10, IL12B,IL12RB, TNF, CRP, APOB, APOE, LIPC, LPA, NOTCH1, VDR, CASR, $O P G, C A L C R, F 2, F 5, F 7$, and ITGB3. Previous studies demonstrated the elevated serum levels of IL- $1 \beta$, IL-6, IL-8, IL-10, IL-12, TNF- $\alpha$, and CRP in patients with IE compared to the healthy blood donors which indicates the possible importance of these cytokines in the clinical course of IE; however, the exact role of these inflammatory molecules in IE remains elusive [11, 34]. Apolipoproteins B and E, lipoprotein (a), and hepatic lipase are involved in the metabolism of lipids that can be important for IE development since patients with IE have lower level of serum high-density lipoprotein cholesterol (HDL) than healthy blood donors; furthermore, low serum HDL level is indicative of a complicated IE course [16]. Another well-established risk factor of IE is heart valve calcification, with NOTCH1, vitamin D receptor, calciumsensing receptor, osteoprotegerin, and calcitonin receptor being the major regulators of serum calcium and phosphorus levels $[27,35,36]$. Finally, patients with IE are prone to thromboembolism due to increased systemic coagulation, activation of platelets, and impaired fibrinolysis [13, 14]. F2, F5, F7, and integrin beta 3 all are crucial proteins responsible for the maintenance of hemostasis $[14,27]$.

Here, we found that the G/A genotype of the rs1143634 polymorphism within the $I L 1 B$ gene, the G/T genotype of the rs3212227 polymorphism within the IL12B gene, the A/ $G$ genotype of the rs1130864 polymorphism within the CRP gene, the A/G genotype of the rs13290979 polymorphism within the NOTCH1 gene, and the G allele of the rs1801197 polymorphism within the CALCR gene were associated with a decreased risk of IE whereas the T/T genotype of the rs1205 polymorphism within the CRP gene was associated with a higher risk of IE. Recent studies by Weinstock et al. [37] and Giannitsioti et al. [38] revealed that the SNPs within the $I L 1 B, I L 6$, and TNF genes can be associated with IE; however, we did not confirm these findings with regard to IL6 and TNF. Small sample sizes, sample differences (e.g., age, gender, ethnicity, and clinical features), and geographical variations in the microbial causes of IE [39, 40] may be responsible for these discrepancies. Since all the SNPs in our study were in Hardy-Weinberg equilibrium, genotyping errors were unlikely to affect the results.

The G/A genotype of the rs1143634 polymorphism within the $I L 1 B$ gene and the G/T genotype of the rs3212227 polymorphism within the IL12B gene were associated with a higher plasma level of IL- $1 \beta$ and IL-12 that may provide an insight into their possible protective role. It has been reported that both cytokines are abundant in the serum of the patients with IE compared to those with other infections [34]; one can explain this as a specific immune response to the bacterial or fungal infection of the heart valves or chambers. We suggest that IL- $1 \beta$ and IL-12 can limit the infection, preventing further progression of IE. However, we did not find the associations of two SNPs within the CRP gene reaching statistical significance with CRP plasma level, although it is also known to be higher in patients with IE compared to other subjects [11]. Other SNPs within the $T N F-\alpha, I L-6, I L-8$, and $I L-10$ genes did not show a predictive 
value and did not correlate with altered levels of the corresponding cytokines.

Our study has a number of limitations. First, the sample size is relatively small due to the low incidence rate of IE; however, this is a common drawback of genetic association studies on IE. With our sample size (123 cases and 300 controls), we had at least $83 \%$ and $99.7 \%$ power to detect odds ratio $(\mathrm{OR})=2$ and $\mathrm{OR}=3$, respectively, with $5 \%$ alpha risk. Unfortunately, it was still impossible to analyze the genetic associations with the features or severity of IE. Second, technical difficulties made it unable to collect information on the potential confounders, that is, alcohol consumption, smoking status, and so forth. Third, we could not properly assess the microbiological profile due to extensive antibiotic therapy of IE at the district hospitals prior to the admission to our clinic. Finally, this study included only those patients requiring surgical treatment, as other patients with IE are not admitted to our clinic due to peculiarities of Russian healthcare.

\section{Conclusions}

Inherited variation within the cytokine, acute phase response, and calcium metabolism genes can be linked to IE, providing additional insight into its pathogenesis. In particular, heterozygous genotypes of the rs1143634 and rs3212227 polymorphisms are associated with both decreased risk of IE and higher level of IL-1 $\beta$ and IL-12, respectively, suggesting their possible importance. Further studies are needed to confirm our findings and for the further understanding of the genetic susceptibility to IE.

\section{Conflicts of Interest}

The authors declare that there is no conflict of interest regarding the publication of this paper.

\section{Authors' Contributions}

Anastasia V. Ponasenko, Anton G. Kutikhin, Leonid S. Barbarash, and Arseniy E. Yuzhalin designed the research. Anastasia V. Ponasenko, Natalia V. Rutkovskaya, Natalia V. Kondyukova, Yuri N. Odarenko, and Yana V. Kazachek recruited the patients with IE. Arseniy E. Yuzhalin recruited the healthy controls. Anastasia V. Ponasenko, Maria V. Khutornaya, Anna V. Tsepokina, and Arseniy E. Yuzhalin isolated the DNA, performed the genotyping, and conducted the enzyme-linked immunosorbent assay. Anton G. Kutikhin carried out the statistical analysis. Anton G. Kutikhin and Arseniy E. Yuzhalin wrote the paper. All the authors have read and approved the final article.

\section{References}

[1] G. Habib, P. Lancellotti, M. J. Antunes et al., "2015 ESC guidelines for the management of infective endocarditis: the Task Force for the Management of Infective Endocarditis of the European Society of Cardiology (ESC). Endorsed by: European Association for Cardio-Thoracic Surgery (EACTS), the
European Association of Nuclear Medicine (EANM)," European Heart Journal, vol. 36, no. 44, pp. 3075-3128, 2015.

[2] T. J. Cahill and B. D. Prendergast, "Infective endocarditis," Lancet, vol. 387, no. 10021, pp. 882-893, 2016.

[3] P. Muñoz, M. Kestler, A. De Alarcon et al., "Current epidemiology and outcome of infective endocarditis: a multicenter, prospective, cohort study," Medicine (Baltimore), vol. 94, no. 43, article e1816, 2015.

[4] A. A. Bin Abdulhak, L. M. Baddour, P. J. Erwin et al., "Global and regional burden of infective endocarditis, 1990-2010: a systematic review of the literature," Global Heart, vol. 9, no. 1, pp. 131-143, 2014.

[5] V. H. Chu, C. H. Cabell, D. K. Benjamin et al., "Early predictors of in-hospital death in infective endocarditis," Circulation, vol. 109, no. 14, pp. 1745-1749, 2004.

[6] J. A. San Román, J. López, I. Vilacosta et al., "Prognostic stratification of patients with left-sided endocarditis determined at admission," The American Journal of Medicine, vol. 120, no. 4, pp. 369e1-367, 2007.

[7] A. Wang, E. Athan, P. A. Pappas et al., "Contemporary clinical profile and outcome of prosthetic valve endocarditis," Journal of the American Medical Association, vol. 297, no. 12, pp. 1354-1361, 2007.

[8] E. E. Hill, P. Herijgers, P. Claus, S. Vanderschueren, M. C. Herregods, and W. E. Peetermans, "Infective endocarditis: changing epidemiology and predictors of 6-month mortality: a prospective cohort study," European Heart Journal, vol. 28, no. 2, pp. 196-203, 2007.

[9] D. R. Murdoch, G. R. Corey, B. Hoen et al., "Clinical presentation, etiology, and outcome of infective endocarditis in the 21st century: the International Collaboration on EndocarditisProspective Cohort Study," Archives of Internal Medicine, vol. 169, no. 5, pp. 463-473, 2009.

[10] S. McNicholas, A. F. Talento, J. O'Gorman et al., "Cytokine responses to Staphylococcus aureus bloodstream infection differ between patient cohorts that have different clinical courses of infection," BMC Infectious Diseases, vol. 14, no. 1, p. 580, 2014.

[11] R. W. Watkin, L. V. Harper, A. B. Vernallis et al., "Pro-inflammatory cytokines IL6, TNF-alpha, IL1beta, procalcitonin, lipopolysaccharide binding protein and C-reactive protein in infective endocarditis," The Journal of Infection, vol. 55, no. 3, pp. 220-225, 2007.

[12] A. S. Golovkin, A. V. Ponasenko, A. E. Yuzhalin et al., "An association between single nucleotide polymorphisms within TLR and TREM-1 genes and infective endocarditis," Cytokine, vol. 71, no. 1, pp. 16-21, 2015.

[13] N. S. Buyukasýk, M. Ileri, A. Alper et al., "Increased blood coagulation and platelet activation in patients with infective endocarditis and embolic events," Clinical Cardiology, vol. 27, no. 3, pp. 154-158, 2004.

[14] E. Durante-Mangoni, R. Molaro, and D. Iossa, "The role of hemostasis in infective endocarditis," Current Infectious Disease Reports, vol. 16, no. 11, p. 435, 2014.

[15] M. İleri, S. Kanat, G. Orhan et al., "Increased mean platelet volume in patients with infective endocarditis and embolic events," Cardiology Journal, vol. 22, no. 1, pp. 37-43, 2015.

[16] G. Kahveci, F. Bayrak, B. Mutlu et al., "Clinical significance of high-density lipoprotein cholesterol in left-sided infective endocarditis," The American Journal of Cardiology, vol. 101, no. 8, pp. 1170-1173, 2008. 
[17] W. F. Elkhatib, P. S. Hair, J. O. Nyalwidhe, and K. M. Cunnion, "New potential role of serum apolipoprotein E mediated by its binding to clumping factor a during Staphylococcus aureus invasive infections to humans," Journal of Medical Microbiology, vol. 64, Part 4, pp. 335-343, 2015.

[18] F. Thuny, J. Textoris, A. B. Amara et al., "The gene expression analysis of blood reveals S100A11 and AQP9 as potential biomarkers of infective endocarditis," PloS One, vol. 7, no. 2, article e31490, 2012.

[19] M. G. Snipsøyr, M. Ludvigsen, E. Petersen, H. Wiggers, and B. Honoré, "A systematic review of biomarkers in the diagnosis of infective endocarditis," International Journal of Cardiology, vol. 202, pp. 564-570, 2016.

[20] A. E. Yuzhalin and A. G. Kutikhin, "Integrative systems of genomic risk markers for cancer and other diseases: future of predictive medicine," Cancer Management and Research, vol. 4, pp. 131-135, 2012.

[21] S. M. Bakhtiar, A. Ali, S. M. Baig, D. Barh, A. Miyoshi, and V. Azevedo, "Identifying human disease genes: advances in molecular genetics and computational approaches," Genetics and Molecular Research, vol. 13, no. 3, pp. 5073-5087, 2014.

[22] G. Habib, B. Hoen, P. Tornos et al., "Guidelines on the prevention, diagnosis, and treatment of infective endocarditis (new version 2009): the Task Force on the Prevention, Diagnosis, and Treatment of Infective Endocarditis of the European Society of Cardiology (ESC). Endorsed by the European Society of Clinical Microbiology and Infectious Diseases (ESCMID) and the International Society of Chemotherapy (ISC) for Infection and Cancer," European Heart Journal, vol. 30, no. 19, pp. 2369-2413, 2009.

[23] Z. Xu and J. A. Taylor, "SNPinfo: integrating GWAS and candidate gene information into functional SNP selection for genetic association studies," Nucleic Acids Research, vol. 37, Supplement 2, pp. W600-W605, 2009.

[24] A. Z. Dayem Ullah, N. R. Lemoine, and C. Chelala, "SNPnexus: a web server for functional annotation of novel and publicly known genetic variants (2012 update)," Nucleic Acids Research, vol. 40, Web Server issue, pp. W65-W70, 2012.

[25] A. S. Golovkin, A. V. Ponasenko, M. V. Khutornaya et al., "Association of TLR and TREM-1 gene polymorphisms with risk of coronary artery disease in a Russian population," Gene, vol. 550, no. 1, pp. 101-109, 2014.

[26] A. G. Kutikhin, A. V. Ponasenko, M. V. Khutornaya et al., "Association of TLR and TREM-1 gene polymorphisms with atherosclerosis severity in a Russian population," Meta Gene., vol. 9, pp. 76-89, 2016.

[27] A. V. Ponasenko, M. V. Khutornaya, A. G. Kutikhin et al., “A genomics-based model for prediction of severe bioprosthetic mitral valve calcification," International Journal of Molecular Sciences, vol. 17, no. 9, 2016.

[28] X. Solé, E. Guinó, J. Valls, R. Iniesta, and V. Moreno, "SNPStats: a web tool for the analysis of association studies," Bioinformatics, vol. 22, no. 15, pp. 1928-1929, 2006.

[29] T. Vollmer, K. Kleesiek, and J. Dreier, "Lipopolysaccharidebinding protein (LBP) gene polymorphisms: rapid genotyping by real-time PCR and association with infective endocarditis," Clinical Biochemistry, vol. 42, no. 13-14, pp. 1413-1419, 2009.

[30] S. Daga, J. G. Shepherd, J. G. Callaghan et al., "Platelet receptor polymorphisms do not influence Staphylococcus aureus-platelet interactions or infective endocarditis," Microbes and Infection, vol. 13, no. 3, pp. 216-225, 2011.
[31] S. Daga, J. G. Shepherd, R. K. Hung et al., "GPIb VNTR C/C genotype may predict embolic events in infective endocarditis," The Journal of Heart Valve Disease, vol. 22, no. 1, pp. 133-141, 2013.

[32] E. Durante-Mangoni, D. Iossa, R. Molaro et al., "Prevalence and significance of two major inherited thrombophilias in infective endocarditis," Internal and Emergency Medicine, vol. 10, no. 5, pp. 587-594, 2015.

[33] J. Bustamante, E. Tamayo, S. Flórez et al., "Toll-like receptor 2 R753Q polymorphisms are associated with an increased risk of infective endocarditis," Revista Española de Cardiología, vol. 64, no. 11, pp. 1056-1059, 2011.

[34] I. R. Araújo, T. C. Ferrari, A. Teixeira-Carvalho et al., "Cytokine signature in infective endocarditis," PloS One, vol. 10, no. 7, article e0133631, 2015.

[35] G. Nucifora, L. P. Badano, P. Viale et al., "Infective endocarditis in chronic haemodialysis patients: an increasing clinical challenge," European Heart Journal, vol. 28, no. 19, pp. 2307-2312, 2007.

[36] T. Doulton, N. Sabharwal, H. S. Cairns et al., "Infective endocarditis in dialysis patients: new challenges and old," Kidney International, vol. 64, no. 2, pp. 720-727, 2003.

[37] M. Weinstock, I. Grimm, J. Dreier, C. Knabbe, and T. Vollmer, "Genetic variants in genes of the inflammatory response in association with infective endocarditis," PLoS One, vol. 9, no. 10, article e110151, 2014.

[38] E. Giannitsioti, G. Damoraki, C. Rokkas et al., "Impact of haplotypes of TNF in the natural course of infective endocarditis," Clinical Microbiology and Infection, vol. 20, no. 5, pp. 459-464, 2014.

[39] M. A. Elbey, S. Akdağ, M. E. Kalkan et al., “A multicenter study on experience of 13 tertiary hospitals in Turkey in patients with infective endocarditis," Anadolu Kardiyoloji Dergisi, vol. 13, no. 6, pp. 523-527, 2013.

[40] K. Gupta, N. Jagadeesan, N. Agrawal, P. Bhat, and M. C. Nanjappa, "Clinical, echocardiographic and microbiological study, and analysis of outcomes of infective endocarditis in tropical countries: a prospective analysis from India," The Journal of Heart Valve Disease, vol. 23, no. 5, pp. 624-632, 2014. 


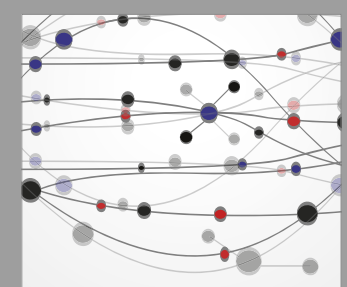

The Scientific World Journal
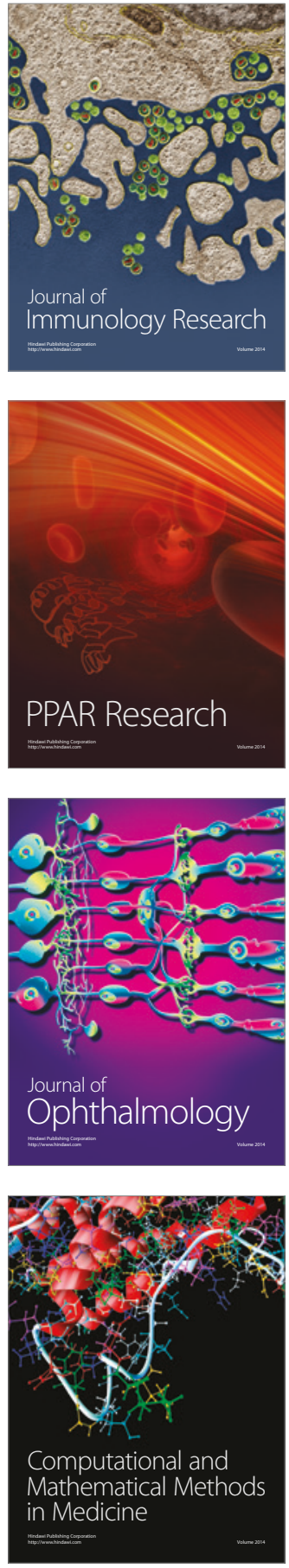

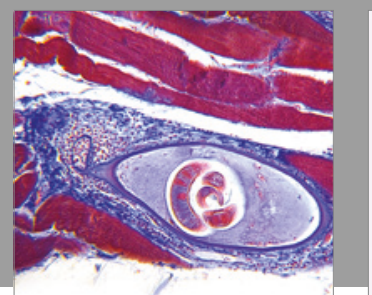

Gastroenterology Research and Practice
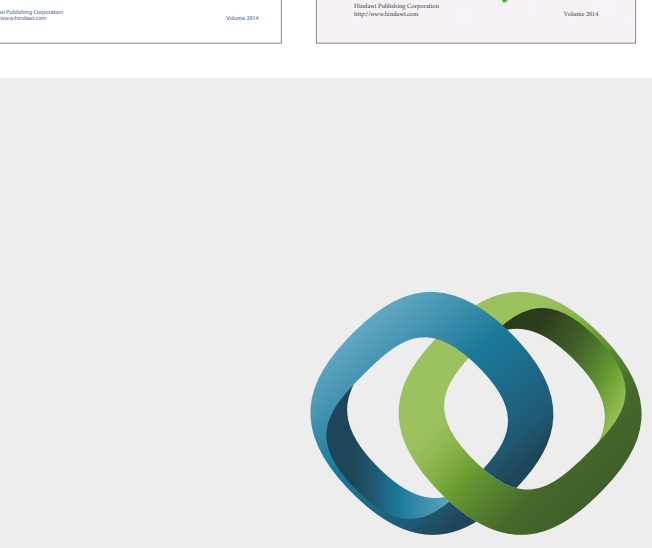

\section{Hindawi}

Submit your manuscripts at

https://www.hindawi.com
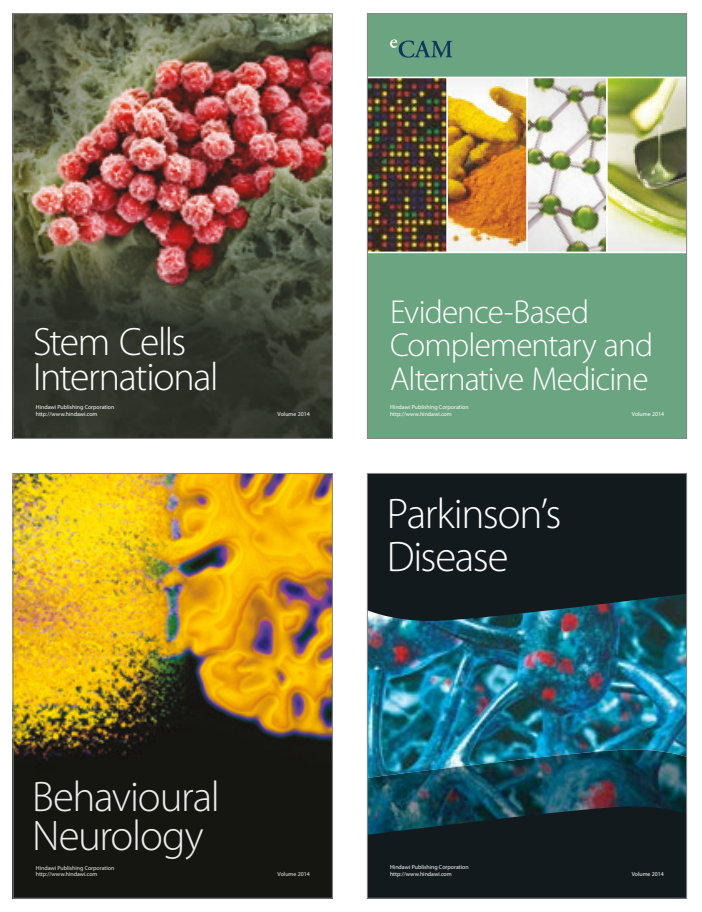
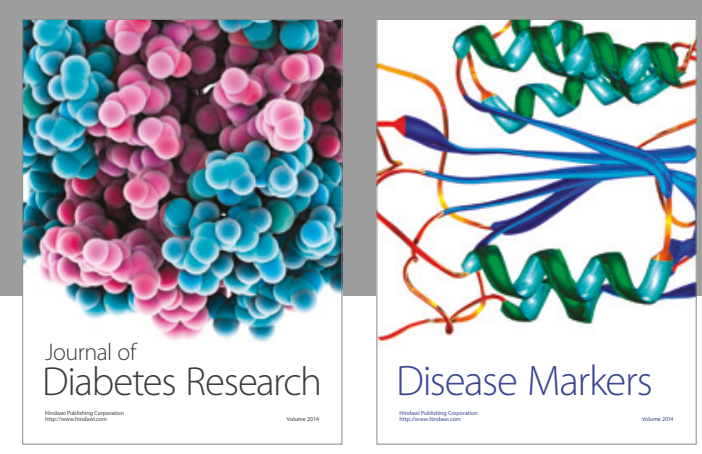

Disease Markers
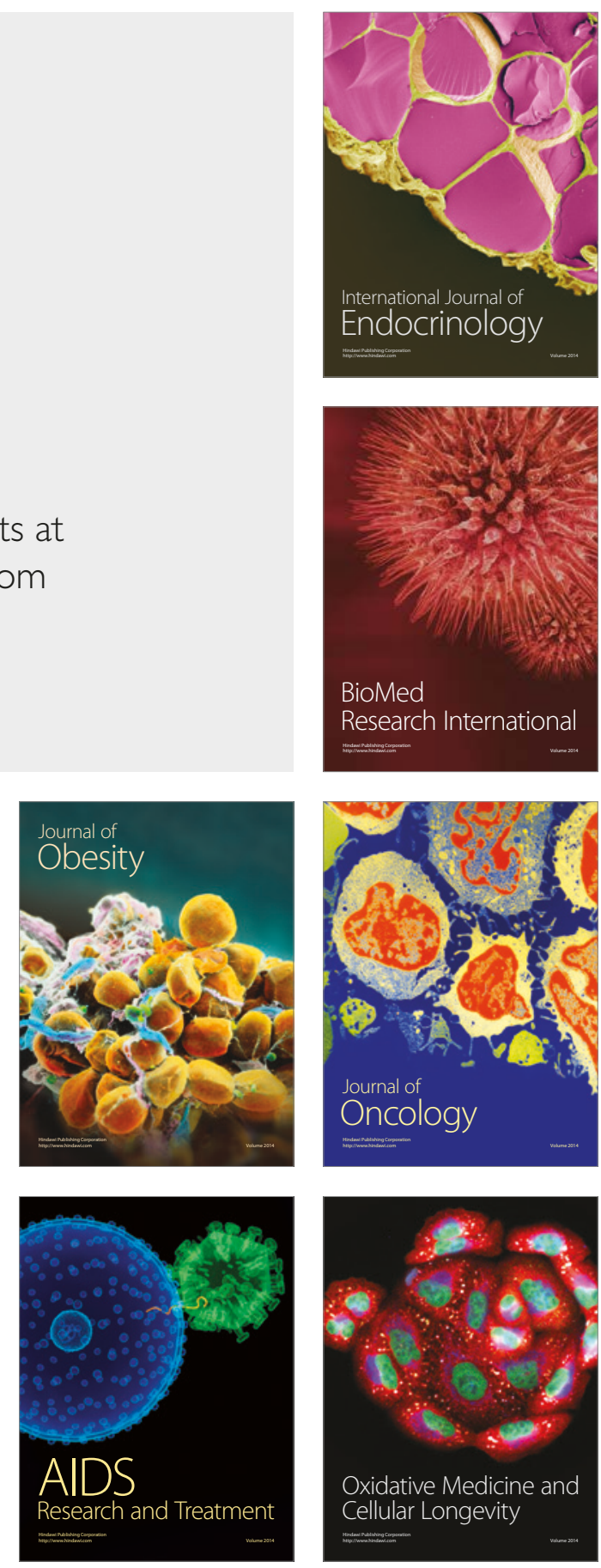